\title{
Premacular haemorrhage in a child with Evans syndrome
}

\author{
Gargi Verma, ${ }^{1}$ Lipika Nayak, ${ }^{2}$ Aparajita Banerjee, ${ }^{1}$ Bhagabat Nayak ${ }^{1}$
}

'Ophthalmology, All India Institute of Medical Sciences Bhubaneswar, Bhubaneswar, Orissa, India

${ }^{2}$ Institute of Medical Sciences and SUM Hospital, Siksha 0 Anusandhan University, Bhubaneswar, Orissa, India

Correspondence to Dr Bhagabat Nayak, bhagabat80@gmail.com

Accepted 25 February 2019
Check for updates

(C) BMJ Publishing Group Limited 2019. No commercial re-use. See rights and permissions. Published by BMJ.

To cite: Verma G, Nayak L, Banerjee $\mathrm{A}$, et al. BMJ Case Rep 2019;12:e229636 doi:10.1136/bcr-2019. 229636

\section{DESCRIPTION}

A 5 -year-old boy presented with sudden onset diminution of vision in his left eye for 5 days. Patient also had history of intermittent bleeding from gums since 7 days. There was history of fever 25 days back for which he was treated with intravenous antibiotics at local hospital and fever subsided. Recurrent history of fever was present since the age of 2 months. Family history revealed death of male sibling at the age of 4 months following a blood transfusion, but the clinical diagnosis was not mentioned in record. No history of blood transfusion was present in this child yet. On general physical examination, there was pallor, generalised lymphadenopathy and mild hepatosplenomegaly. On ophthalmological evaluation, visual acuity was 20/20 in right eye and 20/200 in his left eye. Anterior segment examination was normal for both the eyes. Funduscopy showed a small retinal haemorrhage in inferior quadrant in his right eye and typical premacular haemorrhage in left eye (figure 1A,B). Relevant blood investigations showed haemoglobin $56 \mathrm{~g} / \mathrm{L}$, total leucocyte count $7.28 \times 10^{9} / \mathrm{L} \mathrm{mm}$ and platelet count was $17 \times 10^{9} / \mathrm{L}$. Bone marrow examination showed hypercellularity

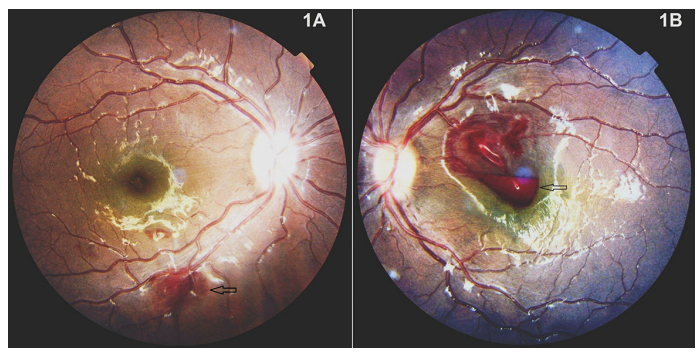

Figure 1 (A) Right eye fundus photo showing retinal haemorrhage near inferior arcade (hollow black arrow). (B) Left eye fundus photo showing boat shaped preretinal haemorrhage over macula with horizontal blood level (hollow black arrow).

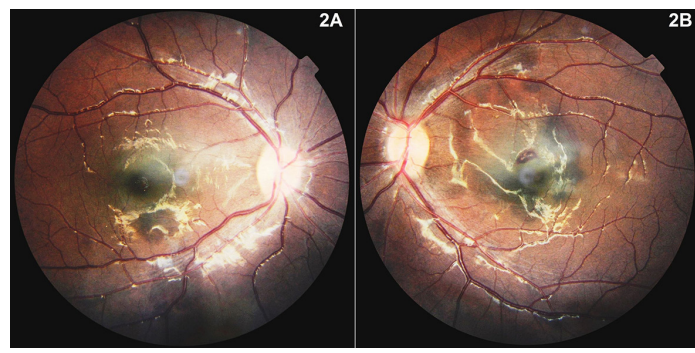

Figure 2 (A) Right eye fundus photo showing resolved retinal haemorrhage after treatment. (B) Left eye fundus photo showing resolved preretinal haemorrhage over macula after treatment. with erythroid hyperplasia and crowding of megakaryocytes. His bleeding time, clotting time, prothombin time and activated partial thromboplastin time were within normal range. Child was transfused with pure red blood cells and platelets multiple times and each time haemolysis was faster with further fall in haemoglobin and platelet counts. So, the patient was further investigated and evidence of antierythrocyte antibodies was found. The diagnosis of Evans syndrome was made due to coexistence of autoimmune haemolytic anaemia (AHA) and idiopathic thrombocytopenia (ITP) in presence of normal leucocyte count. The child was started with intravenous immunoglobins at $1.7 \mathrm{mg} /$ $\mathrm{kg}$ over 3 days and steroids (prednisolone) at $2 \mathrm{mg} /$ $\mathrm{kg} /$ day. Patient improved with no further bleeding manifestations. Although, the fundoscopic findings (figure 2A,B) resolved after 4 weeks, but the treatment was continued for 12 weeks to avoid relapse.

Evans syndrome is a disorder characterised by simultaneous or sequential development of AIHA and ITP and/or immune neutropenia. ${ }^{1}$ It is a relatively uncommon condition. The diagnosis is made by presence of antierythrocyte antibodies detected by direct antiglobulin test in combination with haemolytic anaemia and thrombocytopenia where other causes of thrombocytopenia and haemolytic anaemia excluded. Based on temperatures, at which auto antibodies will react with red blood cells, AIHA is classified as warm and cold antibody types. ${ }^{2}$ Warm antibody AIHA is more common in children less than 12 years. Naithani et $a l^{3}$ reported in their study that AIHA in children is often acute, self-limiting and has a good response to short term steroid therapy. The mechanism of action of steroids is probably down regulation of $\mathrm{Fc}$ receptors on phagocytes and reduced interleukin- 2 production. Clinically significant haemolysis leads to anaemia, jaundice, splenomegaly and maximum patients present with yellow discoloration of eyes, abdominal pain, rash or bruises. Thrombocytopenia leads to nose bleeding, gum bleeding, petechiae, blood in stool and urine. However, in our case, presenting symptom was diminution of vision which led to

\section{Patient's perspective}

My child has recovered in terms of vision and over all general condition after the diagnosis and treatment provided to him since 1 month. I would like to follow-up regularly. I am happy with the overall treatment process. 
the detection of AIHA along with ITP and the diagnosis of Evans syndrome.

\section{Learning points}

- Ophthalmological manifestation may be the initial clinch to diagnosis of a haematological disorder.

- Detailed ophthalmological evaluation is of paramount importance in any bleeding disorder in a child.

- Prompt treatment can lead to early visual rehabilitation.

Contributors GV: conception and design. LN: acquisition of data and correction of manuscript. $A B$ : analysis and interpretation of data. BN: discussion and planning and final submission.
Funding The authors have not declared a specific grant for this research from any funding agency in the public, commercial or not-for-profit sectors.

Competing interests None declared.

Patient consent for publication Not required.

Provenance and peer review Not commissioned; externally peer reviewed.

\section{REFERENCES}

1 Michel M, Chanet V, Dechartres A, et al. The spectrum of Evans syndrome in adults: new insight into the disease based on the analysis of 68 cases. Blood 2009;114:3167-72.

2 Ladogana S, Maruzzi M, Samperi P, et al. Diagnosis and management of newly diagnosed childhood autoimmune haemolytic anaemia. Recommendations from the Red Cell Study Group of the Paediatric Haemato-Oncology Italian Association. BloodTransfus 2017:15:259-67.

3 Naithani R, Agrawal N, Mahapatra M, et al. Autoimmune hemolytic anemia in children. Pediatr Hematol Oncol 2007:24:309-15.

Copyright 2019 BMJ Publishing Group. All rights reserved. For permission to reuse any of this content visit

https://www.bmj.com/company/products-services/rights-and-licensing/permissions/

BMJ Case Report Fellows may re-use this article for personal use and teaching without any further permission.

Become a Fellow of BMJ Case Reports today and you can:

- Submit as many cases as you like

- Enjoy fast sympathetic peer review and rapid publication of accepted articles

- Access all the published articles

- Re-use any of the published material for personal use and teaching without further permission

For information on Institutional Fellowships contact consortiasales@bmjgroup.com

Visit casereports.bmj.com for more articles like this and to become a Fellow 